\title{
Structural Antecedents of Corporate Network Evolution ${ }^{1}$
}

\author{
Frank Wijen \\ Department of Strategic Management and Entrepreneurship \\ Rotterdam School of Management, Erasmus University \\ P.O. Box 1738 \\ 3000 DR Rotterdam, The Netherlands \\ e-mail: fwijen@rsm.nl \\ Niels Noorderhaven \\ Department of Organisation and Strategy \\ Faculty of Economics and Business Administration \\ Tilburg University \\ P.O. Box 90153 \\ 5000 LE Tilburg, The Netherlands \\ e-mail: n.g.noorderhaven@uvt.nl \\ Wim Vanhaverbeke \\ Department of Business Studies \\ Hasselt University \\ Vosken 76 \\ 3210 Lubbeek, Belgium \\ e-mail: wim.vanhaverbeke@uhasselt.be
}

\section{Published in:}

International Journal of Business Environment, 2011, 4(3): 207-233

\footnotetext{
${ }^{1}$ We are very much indebted to Michael Rombouts, working at the Lighting Division of Royal Philips Electronics, for his active contribution to the collection of data.
} 


\title{
Structural Antecedents of Corporate Network Evolution
}

\begin{abstract}
While most network studies adopt a static view, we argue that corporate social networks are subject to endogenous dynamics of cognitive path dependence and selfreinforcing power relations. Over time, these dynamics drive corporate networks to become increasingly focused (i.e., more homogeneous, stable, and tightly knit). More focused networks induce organisations to perpetuate existing routines, at the expense of developing new capabilities. We examine the role of organisational structure in maintaining balanced, rather than focused, networks, so that business organisations can realise progressive and timely adjustments to their evolving environments. We develop a theoretical argument, illustrated with the divergent network adjustment patterns of two large, mature companies, suggesting that business organisations with the following structural antecedents are likely to maintain balanced networks: the concurrence of centralisation and decentralisation; a high degree of differentiation and an intermediate level of integration; and an intermediate degree of formalisation.
\end{abstract}

Key words: social network, organisational structure, routines, evolution 


\section{Structural Antecedents of Corporate Network Evolution}

\section{INTRODUCTION}

Three decades of social network research have spawned numerous insights into the different aspects that make up the relational lifeblood of business organisations. The structures, processes, contingencies, and outcomes of social networks have been theorised and empirically tested at the interpersonal, interunit, and interorganisational levels (for overviews, see Borgatti and Foster, 2003; Brass, Galaskiewicz, Greve, and Tsai, 2004; Parkhe, Wasserman, and Ralston, 2006). At the same time, researchers have predominantly adopted a 'snapshot' view of social networks, often taking existing network structures for granted and (implicitly) assuming that these structures are static. The eschewing of questions regarding network origin and dynamics leaves unanswered important questions as to the factors that account for the emergence and evolution of organisational networks (Brass et al., 2004).

A few studies have addressed the dynamics of social networks. Koka, Madhavan, and Prescott (2006) focused on network responses to exogenous environmental shocks. Hite and Hesterley (2001) discussed network evolution at early stages of corporate development. Gulati and Gargiulo (1999), Baum, Shipilov, and Rowley (2003), Powell, White, Koput, and Owen-Smith (2005), and Kim, Oh, and Swaminathan (2006) studied the endogenous emergence and evolution of interorganisational networks. Drawing on insights from the evolutionary economics literature (e.g, Becker, 2004; Feldman and Pentland, 2003; Nelson and Winter, 1982), our paper also addresses endogenous processes of network evolution. In particular, we focus on the ways in which organisational structure impacts the network development 
patterns of large, mature firms. By addressing the largely uncharted crossroads of organisational structure and network dynamics, we respond to Jacobides' (2007: 470) call that "we should study in greater detail how the division of labor in the organization implicitly leads to a "cognitive architecture," how divisionalization shapes search, and how it affects an organization's ability to adapt and respond." The challenge of organisational structure or design is "to divide the tasks into manageable, specialized jobs, yet coordinate the tasks so that the firm reaps the benefits of harmonious action" (Rivkin and Siggelkow, 2003: 292). Since organisational structures both enable and constrain action (Granovetter, 1985), the particular ways in which organisations divide and coordinate their interdependent tasks will favour or hamper the establishment and maintenance of interactions among (both internal and external) actors. Organisational structure is thus likely to impact network development patterns.

The essence of our argument is that evolving power relations and cognitive experiences tend to shape corporate social networks in such a way that the ties of these networks become ever more stable, homogeneous, and tightly knit. Such focused networks may bear their fruits in the short term since organisations become increasingly skilled at exploiting existing capabilities - as evidenced by the perpetuation of extant routines. But focused networks also hamper organisations in the ability to adapt their capabilities to the requirements of their business environments when the latter change. As a result, organisations whose focused networks become at odds with environmental requirements need to proceed to leapfrog network adjustments such as the acquisition of organisations with the 'right type' of ties. In contrast to this punctuated equilibrium model of network adjustment, other organisations manage to continuously rejuvenate their social networks while also 
fostering existing relations. They thus maintain balanced social networks, which continue to provide the information necessary for both deepening existing capabilities and developing new ones.

The impact of structural antecedents on social network dynamics has, to our knowledge, as yet only been studied in the context of small, entrepreneurial firms (Maurer and Ebers, 2006). We build theoretical arguments pertaining to social network dynamics of large, mature firms, and illustrate these with the different patterns of network development in two major companies, DSM and Philips. We analyse social networks at the organisational level. While recognising the importance of individual-level networks (Burt, 2005) and knowledge heterogeneity (Felin and Hesterly, 2007; Rothaermel and Hess, 2007), we focus on organisation-level networks since the latter are more than the sum of individual networks. Corporate networks include the synergetic interactions between individual networks, which remain unnoticed when merely aggregating personal networks. We are thus interested in network evolution at the organisational level, all the more since we expect the impact of individual actors and their personal networks to be limited in our large, mature focal organisations.

The remainder of the paper is structured as follows. We first detail our empirical method and data. The next section discusses the endogenous dynamics of social networks; brief descriptions of the network evolution of our two focal firms are followed by a theoretical analysis of the forces that shape endogenous evolution towards focused networks. We next identify structural characteristics that enable companies to counter this tendency and maintain balanced networks, illustrated with empirical findings from both firms. We finally discuss the implications of our findings and sketch opportunities for future studies. 


\section{EMPIRICAL EVIDENCE}

The outcomes of this study follow from the constant iteration between insights from the literature and empirical observations. Given the important role of the field insights, we first detail our empirical technique and data sources.

\section{Method and Data}

The case study is an appropriate method to investigate issues characterised by dynamic complexity - particularly 'how' and 'why' queries (Ragin, 1987; Yin, 1994). Since we were interested in an in-depth understanding of why and how structural antecedents shape the evolution of social networks, we chose to perform case studies. Another rationale for applying this method is that case studies lend themselves to exploring research areas for which existing theories fall short (Eisenhardt, 1989; Suddaby, 2006) or lack illustration (Siggelkow, 2007). As the literature does not articulate the interrelations between our focal constructs, we used case studies to explore their interactions.

Following the principle of theoretical sampling or the deliberate selection of cases to ensure that the empirical setting accommodates the focal constructs and relations (Eisenhardt and Graebner, 2007), we selected two companies that were large enough to have complex social networks and old enough to show distinct patterns of network evolution. At the same time, we searched for contrast between a company with a relatively balanced social network and a firm with a focused set of relations. The use of such 'polar types' facilitates the detection of contrasting patterns (Eisenhardt and Graebner, 2007). After a preliminary study, we selected two large, long-lived companies that were active in highly competitive industries: DSM, a 
chemicals company with an apparently balanced social network, and Philips Lighting, the division of Royal Philips Electronics dealing with lamps and related products, which seemed to have a relatively focused network.

We conducted 33 in-depth interviews with managers of the focal organisations over the period April 2004 - January 2008. The selection of managers was guided by their roles as active participants in, and observers of, social networks and corporate structures and practices. To ensure variety and complementarity of views, we interviewed managers at different organisational levels (the corporation (in the case of DSM), the division (at Philips), the business group, and the business unit) and in different substantive areas (general management, corporate strategy and planning, marketing, R\&D, information technology, human resources, and logistics). The interviews lasted one to two hours (with an average length of 90 minutes) and were mostly conducted in the respondent's working environment. Some interviews were open-ended, while others were semi-structured. Respondents reflected on past and present developments. Most interviews were tape-recorded and transcribed, while detailed notes were taken in the remaining interviews. This resulted in 370 pages of transcripts and notes. Follow-up phone calls were made when further clarification was needed. Additional evidence was provided by 230 secondary documents (including policy documents, presentations, articles in magazines, annual reports, and monographs on the companies), electronic media (internet and intranet), and field observations.

The process of data collection, analysis, and interpretation was driven by sensitising concepts, which are interpretive devices that are used as a starting point for a qualitative study (Bowen, 2006). In the view of Blumer (1954), theory is of value only if it can be fruitfully connected with the empirical world. This was precisely our 
concern in conducting the case studies. We wanted to explore the extent to which our theoretically derived concepts and relations were actually grounded on real-life phenomena. The sensitising concepts were either pre-established on the basis of the literature study or emerged as apparently salient during the data analysis process. Relevant passages of our primary and secondary data were related to the different concepts. After a first round of analysis, certain sensitising concepts were merged with others or deleted because they turned out not to be sufficiently relevant. The sensitising concepts were operationalised by looking at concrete manifestations of the initial concepts. For example, we operationalised 'focused networks' as relatively long-lasting, frequent, and intense relations among actors with similar educational backgrounds and professional experiences.

We systematically perused all information sources. We checked for consistency by comparing the views of the different respondents. Further triangulation was obtained by comparing primary data with the various secondary sources and by comparing the individual analyses of different researchers (Yin, 1994). During the process of data analysis, we regularly returned to the literature and compared the preliminary empirical outcomes with our conceptual insights. These combined insights further framed our subsequent data analysis. After having structured salient passages of the different data sources per focal element, we then related these elements to one another to construct a causal chain of evidence per case (Yin, 1994). We considered different causality patterns and analysed which ones were substantiated by the data. Finally, we made a cross-case comparison to assess the similarities and differences of both companies (Huberman and Miles, 1994). The empirical outcomes are represented in the following sections. 


\section{NETWORK EVOLUTION PATTERNS}

How do corporate networks evolve? Are they subject to general forces that lead to isomorphic evolution patterns or do divergent dynamics entail heterogeneous network developments? To explore this question, we studied the network dynamics of two large companies. We start by sketching the company profiles and the composition and evolution of their social networks. After briefly reviewing the impact of network configuration on organisational capabilities, we theorise on the evolutionary dynamics of corporate networks, highlighting the factors that are likely to endogenously shape network development.

\section{Empirical Patterns of Network Evolution}

\section{DSM}

DSM is a Dutch-based firm with global operations in specialty chemicals and materials. In 1902, DSM (Dutch State Mines) was founded as a state-owned coalmining company. After a century of growth and diversification, DSM's portfolio consisted of three clusters: 'Life Science Products' (including biotechnology), 'Performance Materials' (particularly elastomers, resins, and plastics), and 'Industrial Chemicals' (mainly petrochemicals). In response to the increasingly global, competitive, and turbulent business environment of the 1990s, DSM decided to adopt a multiple-specialist strategy and focus on a small number of areas to realise scale economies in research and production (Van Rooij, 2007). The company largely divested its petrochemicals business to the Saudi Arabian company SABIC in 2002 and focused on Life Science Products (later on split into Nutrition and Pharma) and Performance Materials. Each of these businesses is composed of relatively autonomous Business Groups with their own profit-and-loss responsibility. The 
corporate Innovation Center nurtures new businesses based on radical technologies. Despite the divestment of its petrochemicals business, DSM's sales have progressively grown over the past five years, resulting in a 2008 sales figure of EUR 9.3 billion for 23,600 employees. The company shows an average net income before taxes of $10 \%$, which is comparable to the performance of other chemical companies but remarkable in the light of its recent transformation.

DSM has well-developed internal networks. The 'Business Strategy Dialogues' and 'Corporate Strategy Dialogues' are institutionalised networks. These interactive, consensus-seeking processes assure the bottom-up stream of innovative strategic ideas within the firm, at the Business Group and corporate levels, respectively. In the Business Strategy Dialogues, relatively homogeneous groups of managers and other employees discuss how to revitalise their existing businesses. In the Corporate Strategy Dialogues, units engaged in new ventures have discussions with colleagues from short-term-oriented operational businesses, board members, and others about the future corporate strategy. Furthermore, heterogeneous innovation teams of representatives from different Business Groups seek to create synergies by developing new activities that span several Business Groups. The company is also engaged in numerous external networks. Operational Business Groups have frequent value-chainrelated contacts with customers and suppliers to improve existing products and processes. Other entities have relatively weak, heterogeneous, and recent ties with knowledge partners such as universities, research laboratories, and technology-based start-ups to explore new business areas.

DSM's networks were traditionally inward-oriented. Strong ties within Business Groups and weak ties between Business Groups were successful in a relatively stable, technology-driven business environment. External contacts were parsimonious and 
confined to some fundamental research projects with selected universities. When globalisation induced the company to pursue a different strategy, DSM also had to reconfigure its networks. The divestment of the petrochemicals business led to a certain contraction of its social networks. External partners grew increasingly important and the firm started to ever more rely on open innovation to tap into externally developed knowledge (Kirschbaum, 2005). The cooperation with, and direct participation in, external start-ups around the globe became crucial for exploring new but related technological areas. The company also invested in five venture-capital funds focusing on Life Science Products and Performance Materials, leading to 'spin-ins' (i.e, the in-licencing of technologies) once externally developed knowledge has sufficiently crystallised (Meijer, 2006; InterConnect, 2007). In sum, DSM's social network shows a relatively sustained balance, with strong ties within Business Groups being complemented by regular contacts with other Business Groups and with a progressive adjustment of its external network.

\section{Philips}

Philips is a Dutch-based company with global activities in the development, production, and marketing of a variety of electric and electronic products, including Consumer Life Style Products (formerly Consumer Electronics, Domestic Appliances, and Personal Care), Health Care, and Lighting. Philips Lighting, the division on which we have focused our research ('Division'), operates in the area in which Philips has been active since its inception in 1891 (ICFAI, 2005). The Division has progressively evolved from an industrial pioneer in incandescent lighting to a supplier of all kinds of lighting. Being an oligopolist in a predictable industry - together with OSRAM and General Electrics - Philips Lighting has faced relatively stable markets in Western 
Europe and North America. Emerging markets (in particular, Brazil, Russia, China, and India) are much more competitive, complex, and unstable. New technologies (especially LED or solid-state lighting), the shift in orientation from components and products to applications and solutions, and the replacement of incandescent bulbs with energy-efficient lighting have further intensified environmental turbulence in the early 2000s (Bartlett, 2006). The Divison spent EUR 4 billion to acquire several producers and distributors of LED technology and luminaires (including Lumileds, Partners in Lighting, Color Kinetics, and Genlyte) in the period 2005-2008. Philips Lighting has grown strongly over the past five years, leading to a 2008 sales figure of EUR 7.1 billion for 57,000 employees. The Division is market leader and has a relatively high average net income of some $12 \%$.

Philips Lighting's internal networks are predominantly stable, homogeneous, and tightly coupled within Business Groups. Numerous and intensive contacts take place among colleagues who share core values. The similarity of backgrounds of employees in higher functions is relatively strong and is stimulated by tenure length, although 'external blood' has recently enhanced employee diversity. Most information needs are met by relying on existing (internal) sources. While the internal networks of most Business Groups show a strong focus, those of some groups are more loosely coupled and show a certain degree of heterogeneity. Business Groups have few contacts with other Business Groups. The Division used to be reticent in establishing external contacts. Exceptions are key account managers and senior managers, who represent the Division in its contacts with major customers to facilitate the exchange of fine-grained information and to build trust and commitment. The Division also engages in close cooperation with suppliers, production sites, distribution centres, and customers to achieve operational excellence. 
While long-lasting and strong ties tend to reinforce the connections among relatively homogeneous internal and external actors, it was recognised that some markets, such as LED lighting, are highly turbulent and that the Divison did not have the required capabilities to adequately serve these markets. In an effort to enter novel markets in which it had not developed its own research, production, and marketing connections, Philips Lighting acquired a number of leading companies in these markets. Furthermore, the Division hired employees with more heterogeneous backgrounds, stimulated cooperation among, and engaged in partnerships with, small companies that were active in the upcoming markets. These new ties are looser and more heterogeneous in nature than the more traditional ones, which still dominate within the Divison. To summarise, the Division's network consists mainly of relatively disconnected Business Group clusters of homogeneous, stable, and cohesive ties, with a recent leapfrog expansion of externally acquired clusters for novel markets.

The two companies thus differ markedly as to the composition and evolution patterns of their social networks. DSM has over time maintained a relatively balanced network - both internally (with regular contacts within and between Business Groups) and externally (with a continuous search for external adjustments). This contrasts with Philips Lighting's network, which consists of relatively disconnected Business Group clusters and which after a long period of increasing focus has recently evolved through radical external network adjustments. We see within Philips Lighting no equivalent of DSM's continuous search for new ideas in the environment, nor of mechanisms for ensuring diversity of internal networks, like DSM's Corporate Strategy Dialogues. How are these network configurations related to the capabilities of both organisations? And how to account for these divergent configurations and evolution 
patterns? We now provide a brief review of the impact of network configuration on organisational capabilities, followed by a theoretical argument to explain endogenous network evolution.

\section{Network Configuration and Organisational Capabilities}

Social networks consist of internal and external links on which organisations can draw to obtain critical resources, such as information. Organisations that are strongly embedded in social networks have relatively good access to technologies and other resources, strengthening their competitive position (Dyer and Singh, 1998; McEvily and Zaheer, 1999; Uzzi, 1996; Gobbo and Olsson, 2010). Two archetypal configurations are bridging and bonding networks (Putnam, 2000; Adler and Kwon, 2002).

Bridging networks consist of weak, sparsely connected ties. Network actors have few direct connections to one another and communication is limited in frequency and intensity. Such networks are conducive to the generation of a large quantity of heterogeneous information from a variety of sources (McEvily and Zaheer, 1999), so that organisations obtain the insights required to keep up with the turbulence and complexity of their environments (Reagans and McEvily, 2003; Morgan, 1997; Nonaka, 1994) while avoiding the pitfall of developing a dominant view where heterodoxy is not tolerated (Janis, 1972). This network type minimises tie redundancy and leads to the maximisation of nodes and heterogeneity of information (Watts, 1999; Reagans and Zuckerman, 2008), which is important in the face of time and

resource constraints (Hansen, Podolny, and Pfeffer, 2001; Rowley, Behrens, and Krackhardt, 2000). 
Bridging networks are valuable for organisations that seek to broaden their scope and explore new, relatively unrelated activities (Gilsing and Nooteboom, 2005; Gobbo and Olsson, 2010). As the new information needed deviates from the existing knowledge stock, it is unlikely that existing network actors can meet these new needs (Collis and Montgomery, 1998). Instead of tapping from existing sources that have satisfied past information needs, organisations then need to establish contacts with actors outside their existing networks who can offer the qualitatively different knowledge required to explore new types of activities (March, 1991). Since it is unclear upfront which new contacts will yield the needed information, organisations will need to establish a large number of weak relations with heterogeneous actors (Baum, Calabrese, and Silverman, 2000; Rowley et al., 2000; Simsek, Lubatkin, and Floyd, 2003). ${ }^{2}$ The novelty, number, and variety of these contacts ensure the inflow of dissimilar ideas, required to deviate from existing paths and fill knowledge gaps (Wuyts, Colombo, Dutta, and Nooteboom, 2005; Argote, 1999; Nonaka, 1994). Bridging networks are, therefore, conducive to the development of new, unrelated organisational capabilities.

Bonding networks are made up of strong, densely connected ties. Actors have frequent and intensive direct contacts with many other network actors. These networks produce common social norms and sanctions that facilitate the development of trust and cooperative exchanges of information (Coleman, 1988; Uzzi, 1997). This social infrastructure of strong, densely connected ties also creates a common cognitive and normative framework in which actors understand one another (Obstfeld, 2005),

\footnotetext{
${ }^{2}$ It can also be argued that strong ties are required for exploration, since the elaboration of new ideas calls for intensive exchanges of especially tacit information among actors concerned (Hansen et al., 2001; Gilsing and Nooteboom, 2005). The different views can be related to dissimilar definitions of explorative learning: if the latter is confined to the generation and initial combination of new ideas,
} 
and are motivated to overcome barriers to information sharing (Hargadon and Sutton, 1997; Reagans and McEvily, 2003).

The value of bonding networks stems from their ability to provide focus and deepen existing knowledge stocks. Strong ties with a relatively homogeneous pool of actors are instrumental, because the exchange of fine-grained information requires intensive interactions (Rowley et al., 2000; Simsek et al., 2003) and similar technical and normative backgrounds to understand one another and strive towards welldetermined objectives (Wuyts et al., 2005; Nooteboom, 2000). Existing network actors with a strong collaboration track record and an intimate knowledge of existing activities build on, and jointly deepen, organisational knowledge stocks (Weick and Westley, 1996; Weick and Roberts, 1993). Bonding networks thus stimulate the further development of existing organisational capabilities.

While bridging networks thus stimulate the development of new capabilities and bonding networks deepen existing ones, such network configurations may not be invariant. In contrast with the 'Austrian' view of quasi-unconstrained network adaptation, we will now argue that social networks are subject to endogenous dynamics that tend to turn bridging networks increasingly into bonding networks.

\section{Endogenous Network Evolution}

Most network scholars, especially those studying network structures, have adopted a static view, analysing network 'snapshots' at a particular point in time. The literature has remained relatively silent on the evolution of social networks. While the dynamic effects of exogenous factors such as environmental uncertainty and munificence

weak ties are optimal; the further development and implementation of these new ideas calls for stronger ties (Hansen, 1999). 
(Koka et al., 2006) and endogenous interorganisational dynamics (Baum et al., 2003) have been addressed, the impact of endogenous dynamics on the evolution of organisational networks has so far been ignored (an exception is Maurer and Ebers, 2006). Burt's (2005) exploration of network dynamics can be applied to organisations. Invoking the market metaphor of Austrian economics, characterised by movements towards equilibria against the backdrop of unevenly and imperfectly distributed knowledge, Burt argues that network entrepreneurs capitalise on profit opportunities by filling 'structural holes'. They connect otherwise unrelated actors and receive a premium for their role as information brokers. Network entrepreneurs will continue to establish new ties until social networks have become so dense that most actors are directly connected to one another and profit opportunities have faded. Networks have then reached an equilibrium.

While Burt's argument is valuable by recognising that network dynamics may be driven by economic incentives, the underlying assumption of atomic, unembedded network actors is unrealistic since the behaviour of actors is enabled and constrained by the social context within which these actors operate (Granovetter, 1985). Following other scholars adopting an 'embedded' view of network evolution (e.g., Marquis, 2003; Walker, Kogut, and Shan, 1997; Uzzi, 1996, 1997), our argument recognises the critical influence of social context and corporate history on network development. Instead of assuming unconstrained network adaptation driven by entrepreneurial individuals, we argue that network dynamics are path dependent, shaped by collective processes of cognition and power. In particular, we develop the idea that the accumulation of cognitive experiences and the concentration of power render social networks increasingly focused: they tend to become more homogeneous, stable, and tightly knit over time. 
Organisations see their scope evolve from broad to narrow after having entered new areas of business (Nooteboom, 2000). When firms pursue new paths, they establish novel contacts. In this explorative stage, they search for, select, and retain fruitful business opportunities. Organisations do so by establishing a large number of weak ties to optimise the quantity and diversity of information against the backdrop of constrained (human) resources (Baum et al., 2000; Granovetter, 1973). Since it is unknown upfront which ties will turn out to be valuable, organisations will explore a large diversity of options (Baum et al., 2000; Elfring and Hulsink, 2007). At the outset, variety is thus crucial and the organisational scope is very broad. Many explorative ties are, however, ephemeral: they are severed or fade away after a short time because they are not perceived as (immediately) fruitful (Burt, 2002). The outselection of many recent ties and the retention of a limited number of new ties then reduces the initial network variety and organisational scope. As time passes, organisational activities become increasingly exploitative in nature because scarce resources tend to be applied for meeting short-term (exploitative) imperatives and because initially successful practices are self-reinforcing (March, 1991).

Business organisations are likely to stick to initially adopted practices that meet their needs - "the "accidents" of organizational genealogy tend to be perpetuated" (Cyert and March, 1992: 39) - since their behaviour is 'satisficing', rather than optimising. This can be explained from the incapacity of organisations to fully understand and predict the complexity of their business environments (Cyert and March, 1992; Simon, 1976). Organisations use heuristics (i.e., rules of thumb that bias new information in favour of existing mental frames), which favour path dependence since familiar solutions are applied to prevailing problems. As a result, new information tends to be interpreted in the light of existing, retrievable stocks of 
knowledge (Bazerman, 1997; Cyert and March, 1992; Nelson and Winter, 1982). Indeed, the 'absorptive capacity' of organisations is positively related to prior, cognitively close (sources of) information, because organisation members can easily acknowledge and assimilate the importance of such knowledge (Cohen and Levinthal, 1990). Such privileging of existing knowledge practices and areas limits the variety of knowledge search and stimulates the development of a dominant logic among decision-makers, thus leading to cognitive path dependence (Bettis and Wong, 2003). Organisational scope thus tends to narrow down over time and organisational capabilities tend to develop along increasingly established paths. The network implication of cognitive path dependence is that organisations continue established 'valuable' contacts with actors who provide 'more of the same' knowledge. Likeminded actors reinforce their mutual ties (McPherson, Smith-Lovin, and Cook, 2001) because of the perceived (cognitive) benefits of information exchanges (Krackhardt, 1992; Reagans and McEvily, 2003). The accumulation of shared experiences and mutual attachment further reinforces actors to perpetuate long-lasting ties (Kim et al., 2006; Baum et al., 2003; Maurer and Ebers, 2006).

A second time-related effect is the emergence of dominant coalitions between actors owing to power dynamics. Actors who (are perceived to) contribute significantly to organisational performance increasingly accumulate power (Miller, 1993). They obtain additional resources to further enhance organisational performance (Hiller and Hambrick, 2005). As a result, 'successful' actors obtain a relatively central and hence powerful position in the organisational network, since other actors rely on their resources (Brass and Burkhardt, 1992; Koka et al., 2006) and, hence, organisations become increasingly dependent on them (Steier and Greenwood, 2000). These 'successful' actors are likely to form dominant coalitions with other actors who 
have proven to be 'successful' (Gulati, 1995; Gulati and Gargiulo, 1999; Baum et al., 2003) and to marginalise or exclude actors whose added value is perceived as insufficient, or whose inputs do not visibly pay off in the short run (Denrell and March, 2001). Their competencies may be related to areas that the dominant coalitions within organisations do not wish to exploit because the existing activity fields are perceived to be more important (Bettis and Wong, 2003; Dougherty and Hardy, 1996). This entails a self-reinforcing process of power accumulation and exclusion in which few new contacts are established, and relations with 'unsuccessful' or 'heterodox' actors are terminated (McPherson et al., 2001; Levitt and March, 1995; Miller, 1993). This process of convergence is likely to continue as long as organisational performance is sufficiently high, because the latter provides legitimacy to dominant actors and precludes the necessity to change (Baum, Rowley, Shipilov, and Chuang, 2005; Johnson, 1988; Tushman and Romanelli, 1985). Power dynamics thus reduce the organisational scope and create inertia.

In sum, cognitive and power dynamics lead to path dependence with selfreinforcing processes that tend to decrease network diversity and increase tie strength and duration. The concomitant exploitation of existing practices will increasingly crowd out the exploration of new activities (Benner and Tushman, 2002). An important consequence of this endogenous process of network focusing is that the (internal and external) organisational network may gradually become less fit when the external environment changes (Burgelman, 2002; Steier and Greenwood, 2000; Tushman and Romanelli, 1985). Indeed, attachment to existing network actors impedes organisational network reconfiguration, even when these actors no longer provide the required resources (Seabright, Levinthal, and Fichman, 1992). As a result, initially formed networks, even when non-optimal, may persist over time and ensue 
path dependence (Walker et al., 1997; Marquis, 2003). Yet, as illustrated in our cases, some organisations succeed in overcoming this network inertia (Kim et al., 2006) and reorient their strategic scope to coevolve with their changing environments (Lewin and Volberda, 1999; Volberda and Lewin, 2003), while others fail to do so (Hannan and Freeman, 1984, 1989; Romanelli and Tushman, 1994). This raises the question of why some organisations are better than others at avoiding the trap of increasing network focus.

\section{STRUCTURAL ANTECEDENTS OF NETWORK EVOLUTION}

We have argued that social networks have an endogenous tendency towards less diversity, increased stability, and enhanced tie strength, but we have also suggested that this tendency may be mitigated by particular organisational antecedents. We now argue that the ways in which organisations are structured to divide and coordinate activities will affect their patterns of social interaction, both within the organisation and across organisational borders. In line with Miller and Dröge (1986), we focus on three important determinants of organisational structure: the locus of decision-making power, the degree of specialisation and integration, and the importance of formal rules. These elements have important influences on power dynamics and cognitive processes, and hence on the formation and development of network ties.

Our reasoning is that organisational structure parameters impact on both the power dynamics and the cognitive processes that lead to the tendency towards increasing network focus. Organisational structure is directly, practically by definition, connected to the power relations within the firm. The endogenous network dynamics described in the previous section are partly linked to (changes in) the organisational structure. For example, organisational structure enables and constrains a dominant 
coalition to accumulate power and marginalise less central players in the firm. Likewise, organisational structure 'channels' cognitive processes by facilitating or hampering information-processing interactions. We maintain that structural parameters will also indirectly impact on organisational network dynamics. This indirect influence works through the organisational routines that are closely connected to the development and maintenance of corporate social networks.

Routines are repetitive, recognisable patterns of interdependent actions, which involve multiple actors (Feldman and Pentland, 2003; Pentland and Feldman, 2005). Routines, which constitute repositories of organisational capabilities (Becker, Lazaric, Nelson, and Winter, 2005), are thus the outcomes of sustained interactions among actors. Social networks embody such interactions. Network configuration - in terms of heterogeneity, stability, and strength of contacts - shapes the development of routines. Interaction patterns among diverse actors are different from those among relatively homogeneous actors. Stable network contacts entail more repetitive interactions than recently established contacts. And relatively strong ties are conducive to the transfer of tacit knowledge and the coordination of actions (Hansen, 1999; Nonaka, 1994), thus also affecting routines.

But routines - once established through network interactions - also recursively affect the development of these social networks. Feasible routines, which provide satisfactory responses to prevailing organisational problems, lead to cognitive path dependence. Network actors build upon existing moulds to further elaborate and refine the adopted cognitive solutions, thus entailing a reinforcing cognitive loop between organisational routines and networks. Satisficing routines also provide power and legitimacy to actors who (are perceived to) have made an important contribution to the initial adoption of feasible organisational practices, while heterodox actors 
become more peripheral. Actors perceived as successful will reinforce the initial frames, thus strengthening their positions and entailing an amplifying relationship between routines and networks.

While the stabilising effect of routines has been amply described in the literature (e.g., Nelson and Winter, 1982; Cyert and March, 1992; Levitt and March, 1995), routines are increasingly regarded as sources of both stability and change. Instead of viewing organisations as mindlessly, habitually, and automatically repeating past interaction patterns, several authors (e.g., Becker et al., 2005; Feldman and Pentland, 2003; Howard-Grenville, 2005) have argued that organisations can also mindfully, consciously, and reflexively interpret the past and present to reshape future interaction patterns. Feldman and Pentland (2003) and Pentland and Feldman (2005) distinguish between the ostensive and performative aspects of a routine, whereby the former constitutes the routine's 'structure' or 'script' and the latter its 'agency' or 'play'. The ostensive aspect provides shared targets, sense-making, and references, whereas the performative aspect consists of the creation, maintenance, and modification of interaction patterns. This perspective provides the ontology for both stability and change of routines.

We will now discuss how the three types of organisational antecedents mentioned above (centralisation-decentralisation, differentiation-integration, and formalisation) are likely to affect endogenous network dynamics.

\section{Centralisation and Decentralisation}

Centralisation refers to the concentration of decision-making power within the organisation, while decentralisation concerns its dispersion (Mintzberg, 1979). In their extreme forms, both centralisation and decentralisation lead to focused networks. 
Centralisation of decision-making enables top management teams or other central bodies, who oversee and manage a portfolio of different activities and units, to wield their formal power to overcome resistance from entrenched interests at lower levels (Normann, 1971), block existing routines to reframe organisational attention and practices (Jacobides, 2007), and reconfigure the social networks of their organisations, e.g., through job rotation or 'switching' (Adler, Goldoftas, and Levine, 1999), by imposing collaboration between organisational units that previously operated in isolation (Argote, 1999), or by forming strategic alliances with other organisations (Hagedoorn, 2006). Such new combinations of actors and units strongly favour the development of innovative routines (Becker et al., 2005). Centralised decision-making also enables organisations to prescribe rules to promote change, thus fostering the development of 'metaroutines' (i.e., routines to change routines) - and in this way corporate innovation may be institutionalised (Adler et al., 1999). These metaroutines may thus encourage network rejuvenation to achieve new products and processes, and enable organisations to break through lower-level (e.g., divisional or business-group) cognitive or power barriers to change and 'force' network reconfiguration or innovation-stimulating routines in a top-down way.

But a high degree of centralisation entails drawbacks. It will lead to control of top managers and central bodies over the internal and external ties of organisational actors (Mintzberg, 1979). By detailing the activities of individual units and organisational members, the latter will have neither the discretion nor the motivation to revitalise their networks (Thompson, 1969). Central planning in large organisations is highly complex, since myriads of parameters need to be considered simultaneously (Simon, 1973). Especially when interdependencies among organisational actors and units are strong, central planning needs to align and coordinate a multitude of actors 
and factors. Feasible decisions, once achieved, will not be readily reconsidered because of (potentially adverse) repercussions on other organisational activities (Cyert and March, 1992), which would jeopardise the attained 'truce' and yield resistance from other organisational actors and units (Nelson and Winter, 1982). Furthermore, the cognitive complexity of centralised decisions in large organisations makes it hard to oversee the ramifications of alternative paths, stimulating a 'muddling through' style without conducting major changes (Lindblom, 1959). As a result, central planners will have a low propensity to continuously adjust satisficing decisions (Starbuck, 1985), both because of their complexity and the intertwinement of divergent interests. The network implications are that existing contacts will not be readily reshuffled, thereby strengthening existing ties and stabilising existing networks. Likewise, central decision-makers will be reluctant to induce changes of existing routines.

Decentralisation offers the opportunity to flexibly adjust networks and routines to environmental changes. Maurer and Ebers (2006) found that, in small biotechnology startups, delegation of relationship management from the founder to other firm members - a form of decentralization - helped in avoiding external network inertia. We expect that decentralisation, up to a certain level, has the same effect in large firms. Organisational units may decide to sever obsolete ties and establish promising new, diverse ties to develop novel practices to re-establish a fit with their (turbulent) business environments, without being constrained by centrallevel interference or interdependence with other units (Volberda, 1996; Thompson, 1969; Mintzberg, 1979). Decentralisation also provides leeway for autonomous units to replace outdated routines with practices that meet the demands of evolving business environments (Tushman and O'Reilly, 1996). Furthermore, decentralisation boosts the 
motivation and creativity to search for new, diverse contacts to develop novel routines (Pierce and Delbecq, 1977). Without the cognitive complexity and interest multiplicity of centralised decision-making, units are capable and motivated to deploy the agility to reframe their routines by changing their target and performance levels.

Extreme decentralisation, however, favours inertia. Dominant actors in autonomous units will build and maintain 'ingroups' or cliques (Wasserman and Faust, 1994) that maintain extant local routines (Jacobides, 2007), both to reinforce their own power (Miller, 1993) and because of myopia or quasi-blindness to opportunities which are relatively far from their own activities (Levitt and March, 1995). While having the option to continuously adjust their networks, complete autonomy induces powerful actors at the decentral level to rely on 'old boys' networks, implying the reinforcement of ties in stable, relatively homogeneous networks (McPherson et al., 2001). Furthermore, the relative isolation of autonomous units favours 'groupthink' because of the development of hubris and a tunnel vision (Janis, 1972). Hubris, propinquity, and the non-interference of divergent (central) devil's advocates may lead to overstretched cognitive path dependence. Power concentration and myopia at the decentral level will also lead to rigid routines, since existing practices are not being questioned.

The focal cases illustrate the above argument. Originally a very centralised company, DSM started to decentralise in the 1990s. At present, many innovationrelated activities are to a large extent the responsibility of the Business Groups, but at the same time central coordinating mechanisms have been installed, such as the Corporate Research Board (Meijer, 2006). Furthermore, DSM has not only Business Strategy Dialogues to better exploit ongoing activities (decentrally), but also centrally steered Corporate Strategy Dialogues, involving the company's top-30 managers, to 
explore new ventures stretching across units (Vanhaverbeke and Peeters, 2005), thus establishing new, weaker, and more heterogeneous internal ties. The company sets clear central boundaries but also decentralises decision-making authority to Business Groups (Van Rooij, 2007). This is exemplified by R\&D, whereby $20 \%$ of the budget accrues to centrally assigned priorities (such as nanotechnology and 'bioterials' (i.e., bio-based products), stretching across different Business Groups), while the remaining $80 \%$ are spent on Business Group projects. DSM also establishes and fosters numerous external ties, especially with $R \& D$ partners (universities, start-up companies, ...) - some of which are located on the premises of DSM's 'open campus'. Many of the external ties, which are driven by both corporate and decentral actors, are recent and substantively different from the existing contacts.

By contrast, Philips Lighting's social network is made up of clusters of strong, stable, and relatively homogeneous ties within highly autonomous (decentralised), product-oriented Business Groups. Each Business Group bears the quasi-entire responsibility of its own strategic course of action and financial results. While the Division sets some strategic directions, the decision-making discretion resides largely in the Business Groups. There are very few ties across different Business Groups to explore new, joint ventures, although recent attempts have been made to intensify collaboration across Business Groups. As one interviewee told us, "the bonds within Business Groups are at least a factor five stronger than the [divisional] community bonds". External ties are relatively stable and strong, aiming at the further reinforcement of existing activities. The Division seeks to refine existing routines, for instance, through the pursuit of operational excellence, rather than to develop new types of practices. 
Since extreme forms of both centralisation and decentralisation will favour the development of focused networks and sticky routines, a balanced network calls for a blend of central and decentral decision-making. Centralisation provides the power and helicopter view to supersede the interests and scopes of individual units, while decentralisation favours the grassroots identification of new opportunities and the discretion to flexibly adjust to altered environmental conditions. The combination of centralisation and decentralisation is thus conducive to the continuous development of new, weak, and diverse network ties. DSM, with its relatively balanced social network, has such an intermediate degree of centralisation. This situation contrasts with Philips Lighting, which has both a highly focused network and a strong tendency towards decentralisation. The focal cases thus illustrate our above argument, which we summarise as follows:

Proposition 1: The concurrence of centralisation and decentralisation fosters the development of balanced corporate networks.

\section{Differentiation and Integration}

While centralisation and decentralisation refer to the vertical or hierarchical division of authority, differentiation and integration refer to the horizontal or heterarchical division and coordination of tasks (Nonaka, 1994; Miller and Friesen, 1982). Differentiation or 'partitioning' concerns the specialisation of tasks over different units, while integration pertains to the coordination of specialised tasks (Adler et al., 1999). Differentiation enables specialised units to focus on just a part of the overall activities, without being directly constrained by activities in other units. As a result, units have ample room to manoeuvre relatively independenly, which enhances their operational flexibility (Adler et al., 1999; Volberda, 1996). A differentiated structure 
also protects new activities, which are vulnerable since they are typically infested with uncertainties and can have long lead times before paying off. Creating specialised units for new ventures reduces the risk of being croweded out by existing activities (Benner and Tushman, 2002; Galbraith, 1982). The existence of a variety of units or localised subsystems involves tight coupling within units with loose coupling between units (Simon, 1973; Gupta, Smith, and Shalley, 2006), thus combining the efficiency advantage of the former with the adaptiveness benefit of the latter (Eisenhardt and Bhatia, 2002; De Visser et al., 2010).

The network implication of differentiation is that different clusters of organisational subnetworks or cliques develop relatively independently from one another, without the constraints of power games or cognitive frames that prevail in other subnetworks (Maurer and Ebers, 2006). This fosters a corporate porfolio of diverse, adjustable ties which can easily match the requisite variety of evolving business environments (Volberda, 1996). Adding new units to nurture novel activities further stimulates the development of new, diverse network ties without being constrained by existing spheres of influence (Ruef, 2002). Likewise, a variety of routines can flourish and co-exist within the organisational boundaries without entailing immediate conflicts over the alignment of routines or the choice of the 'optimal' routine (Benner and Tushman, 2003; Adler et al., 1999).

Differentiation also entails drawbacks. The relative autonomy of individual units may give rise to groupthink and local fiefdoms within each clique, as described above. Furthermore, a certain degree of interdependence among specialised units exists in virtually all organisations, calling for alignment and coordination (Nooteboom, 2000). Examples are the joint use of a particular technology and the combination of different functional departments (R\&D, procurement, operations, 
marketing, ...) to realise a finished product. Therefore, different units will generally have to collaborate to turn inputs into outputs, involving the need to exchange information (Daft and Lengel, 1986). Consequently, different subnetworks have to be intertwined and different routines have to be compatible, at least to a certain degree (Dougherty and Hardy, 1996; Miller and Friesen, 1982). This interdependence of subnetworks and routines sets limits to unit autonomy itself, as well as to the identified advantages of autonomy in terms of network diversity.

Integration is thus required to overcome the drawbacks of differentiation. Alignment and coordination to obtain systemic integration and synergies from collaboration involve extensive communication (Brown and Eisenhardt, 1997), including 'strategic conversations' (Dougherty and Hardy, 1996). Network redundancy is, therefore, not a source of inefficiency but a bare necessity to find sufficient common ground in developing joint cognitive frames and practices (Nonaka, 1994; Reagans and Zuckerman, 2008). A partial integration of different routines may also be required to obtain compatibility or alignment of interconnected product and process elements (Simon, 1973). At the same time, activities should not be so tightly integrated that there is, de facto, no longer a differentiated structure. This suggests that an intermediate degree of integration meets the need of alignment and coordination, while leaving ample room for differentiation. This assertion resonates with Maurer and Ebers' (2006) finding that, in small entrepreneurial firms, integration of relationship management leads to social network inertia if not accompanied by some relationship management differentiation.

The focal cases show these effects of differentiation and integration. DSM has relatively autonomous Business Groups, each operating on differentiated product markets. The company also experiments with new activities, which are initially 
protected in separate (external) units. As the CEO indicates, "We are also moving innovation into business development units so people can be free from the distraction of urgent tasks." Later on, these novel activities are insourced and integrated with existing activities, provided they are sufficiently promising, so that these new, weak, and diverse ties enrich the existing social network. DSM also stimulates synergetic, cross-unit collaborative platforms, for instance, through the Corporate Strategy Dialogues, the Corporate Research Board, annual corporate conferences, and the DSM Business Academy. Bioterials, operating at the intersection of biotechnology and chemical processes, illustrates intensive collaboration across Business Groups. The company also integrates novel and existing activities in 'Emerging Business Areas', which are - as an innovation manager explains - "areas where current market strongholds and technological capabilities align most precisely with societal and technological trends."

Philips Lighting has highly autonomous Business Groups, which hardly collaborate. According to a human resources manager, "I experience that all Business Groups are technology driven and quite closed. It is the history, it very much driven by where we come from as Lighting." While the Division also shields new ventures (such as LED activities) in separate units, they are not actively integrated with existing activities. A Divisional Management Team member: "One needs to get a feeling of these new [recently acquired, innovative] businesses, which one does not get by integrating them. This gives rise to the fish bowl effect, where they [the new businesses] do their business and we have [the existing] businesses watch, certainly not interact or tell how they should behave, just watch." As a result, while Philips Lighting increases the recency and diversity of its ties by acquiring innovative businesses, the different Business Groups are not actively integrated, which fosters the 
development of local network clusters and hampers the maintenance of balanced network ties.

Proposition 2: The combination of a high degree of differentiation and an intermediate degree of integration favours the development of balanced corporate networks.

\section{Formalisation}

While the above antecedents refer to the vertical and horizontal relations between different units, the way in which activities within different units are organised is also important. Formal rules (such as written codes of conduct and standard operating procedures) enable the behaviour of organisational members within specified bounds (cf. Kieser, Beck, and Tainio, 2001), while restricting the discretion or freedom that organisational members enjoy to organise activities as they deem most appropriate (cf. Thompson, 1969).

Formalisation reduces uncertainty and complexity, enhances efficiency, provides an organisational memory of condensed experiences, and (de)legitimises actions by providing clear guidelines to organisational members as to expected and undesired behaviour (Kieser et al., 2001), thus providing the organisational backbone that avoids chaos (Brown and Eisenhardt, 1997). In complex organisations, these rules should be kept as clear and simple as possible to be effective (Eisenhardt and Bhatia, 2002). Paradoxically, formalisation enables organisational members to act since official rules shield actors from the vagaries of personal or ingroup power games or cognitive frames (Kieser et al., 2001). While the contents of formal rules may be more or less enabling, rules free actors from the personal spheres of influence of other network actors since actors can legitimately develop new, diverse contacts and 
practices. Especially rules that tolerate or encourage novelty and innovation stimulate network rejuvenation (Adler et al., 1999). By the same token, rules may also protect or stimulate the development of new routines, unconstrained by personal or ingroup influences.

Formalisation also has its downsides in terms of maintaining balanced networks. Aiming at the achievement of standardisation of inputs, processes, or outputs (Mintzberg, 1979), formalisation may, purposefully or inadvertently, encourage single-mindedness, conformity, window dressing, and excessive control, and reduce commitment and creativity. These constraining effects of rigidity dissuade both the development of new, diverse network ties and the creation of novel routines. Formal rules induce actors to focus their limited attention on the explicitly stated goals and guidelines, thereby becoming blind to relevant yet unspecified environmental developments (Cyert and March, 1992). Conformity and isomorphic behaviour result from the widespread adoption of prevailing (formal) rules and practices (DiMaggio and Powell, 1983), which is at odds with 'out-of-the-box' thinking. Window dressing is geared towards the apparent compliance with (formal) rules, rather than coping with adequate responses to evolving organisational problems (Meyer and Rowan, 1977). Stringent (formal) control acts as a straightjacket that thwarts deviant behaviour (Das and Teng, 2000). The decrease of commitment is a motivational brake on actors who should 'go the extra mile' beyond present contacts and practices (Gagné and Deci, 2005). Reduced creativity entails a lesser imagination of the opportunities of other contacts and practices (Kieser et al., 2001). Excessive formalisation thus fosters homogenisation, stabilisation, and strengthening of existing networks, as well as the perpetuation of existing routines. 
A lack of formalisation thus fosters motivation and creativity since actors have the freedom to deploy new activities in their own ways. Identification with individual or team-developed projects and out-of-the-box thinking are strong stimuli to rejuvenate and diversify network ties. At the same time, this network reconfiguration may never materialise since new projects, in the absence of legitimising rules, encounter resistance from existing power configurations (Dougherty and Hardy, 1996). Furthermore, the absence of rules that 'push' actors to break through existing mental frames or practices may keep actors from actually seizing these opportunities (cf. Porter and Van der Linde, 1995). In sum, an intermediate level of formalisation, striking a middle ground between rigidity and flexibility (Das and Teng, 2000), favours the maintenance of balanced networks. Such an intermediate level of formalisation is reminiscent of the partial order of 'semistructures', which prescribe some aspects of behaviour or outcomes but leave others open (Brown and Eisenhardt, 1997; Vlaar, Van den Bosch, and Volberda, 2007). These provide enough guidance and protection to develop new, diverse network ties and routines without stifling such initiatives through excessive rule-setting.

The case companies illustrate the above argument. DSM has clear formal rules, such as those prescribing the Business Strategy Dialogues and the Corporate Strategy Dialogues. The company's Chief Technology Officer notes that "these consultations are innate to our existing structure of meetings. At my previous employers I have never seen such a [formally] structured process" (InterConnect, 2007). The company also grants considerable autonomy to its employees, but retains a certain degree of formal control. According to the CEO, "Often when people talk about innovation they talk giving employees' freedom to be innovative and out of that you will innovate. I don't believe that is the only element. I believe you also need [formal] boundaries." 
The company's ample, but not unlimited room for deploying new activities is exemplified by the discretion to engage in numerous spin-offs, spin-ins, and collaborative platforms with external actors in specific areas, which have been formally designated by DSM's Top Management Team. The intermediate level of formalisation at DSM has been conducive to the maintenance of a balanced network.

Philips Lighting, with its focused network, is a highly formalised organisation. It has traditionally been a bureaucratic organisation and top managers have, despite repetitive attempts, not succeeded in substantively changing this imprint (Metze, 1997). The bureaucratic character is evidenced by the high number of formal meetings, the production of endless series of staff reports to support decision-making, and the development of a series of control instruments. Standardised quantitative tools and methods (such as key performance indicators, business-balanced scorecards, and process survey tools) are extensively used to achieve operational excellence and "to avoid that we re-invent the wheel." These formal instruments are advocated using slogans such as "what doesn't get measured doesn't get done," "expect what you inspect," and "you are your numbers." As an employee echoes, "I know that to be successful in my job, I have to be result-driven and make my deliverables and progress visible to the management." The Division's extensive formalisation is also illustrated by its management development programme and succession planning, where two potential successors are appointed for each key position. The high degree of formalisation at Philips Lighting is not conducive to the establishment of new, diverse, and weak ties.

Proposition 3: An intermediate level of formalisation fosters the development of balanced corporate networks. 


\section{DISCUSSION AND CONCLUSION}

We have analysed the endogenous dynamics of social networks and the different ways in which organisations intervene with these dynamics. While several studies (Koka et al., 2006; Hite and Hesterly, 2001; Gulati and Gargiulo, 1999; Baum et al., 2003; Powell et al., 2005; Kim et al., 2006; Maurer and Ebers, 2006) have addressed network dynamics, these studies have focused on start-ups, small entrepreneurial firms, interorganisational relations, or organisational fields. Our study adds to these contributions by addressing social network dynamics of mature firms at the organisational level. In particular, we focused on why and how organisational networks evolve - in terms of changes in the diversity, duration, and strength of ties. We developed a theoretical argument and performed comparative case studies to further shape our ideas. Iterating between our conceptual ideas and field observations, we came to convergent insights, in that the social networks of organisations are subject to endogenous dynamics that increasingly privilege bonding over bridging ties, but that these dynamics are influenced by the structural antecedents of organisations.

Network configurations are important because they constitute the informational infrastructure of organisations and are, as a result, an important determinant of their capabilities (Gobbo and Olsson, 2010). Bridging networks are conducive to exploration, while bonding networks foster the exploitation of existing activities. Our theoretical argument and empirical insights suggest that the increasing importance of bonding networks predispose organisations ever more towards an exploitative trajectory. This entails the danger that highly focused organisations can no longer effectively respond to environmental changes. Rather than adopting a deterministic view in which 'unfitting' organisations are outselected (Hannan and Freeman, 1984, 1989), we linked managerial intentionality to network adaptation in order to explain 
how business organisations can coevolve with their changing environments (Lewin and Volberda, 1999; Volberda and Lewin, 2003). In particular, we identified three types of organisational antecedents that help organisations to counter endogenous 'focusing' dynamics and maintain balanced networks that enable organisations to simultaneously meet short-term exploitative demands and keep abreast of longer-term, substantive changes.

On theoretical grounds, illustrated by empirical observations, we conclude that organisations with the 'right' structural antecedents seek to continuously balance their social networks in order to coevolve, in a progressive and timely way, with their business environments. The empirical evidence also suggests that organisations with 'underdeveloped' structural antecedents pass through less frequent but much more profound network adaptations to acquire more bridging ties when their existing networks of predominantly bonding ties no longer suffice to respond to environmental jolts (such as disruptive external innovations) or initiate strategic changes (like reducing time-to-market). The importance of organisational structure is elucidated by our empirical insight that DSM, the organisation with the more interconnected units which on conceptual grounds was likely to follow a punctuated equilibrium trajectory since interdependence thwarts progressive adjustment (Gupta et al., 2006) - made more frequent and progressive network adjustments than Philips Lighting, the organisation with the more autonomous units, because DSM had designed its organisational structure in a way that facilitates progressive network adjustments.

Our finding with regard to the importance of combining clear differentiation and a certain degree of integration resounds with insights from the ambidexterity literature, which argues that this combination is conducive to the organisational ability to simultaneously exploit and explore (Duncan, 1976; Tushman and O'Reilly, 1996; 
O'Reilly and Tushman, 2004; De Visser et al., 2010). However, several of our findings deviate significantly from those of the ambidexterity literature, which contends that a high degree of decentralisation and a low level of formalisation are conducive to ambidexterity. Our reasoning with regard to social network dynamics and our comparative case analysis lead to the more nuanced suggestion that both complete decentralisation and the absence of formalisation may actually promote network focus, and thus, over time, be detrimental to ambidexterity. Just like free markets only blossom when an adequate set of centrally issued, formal 'rules of the game' are in place (North, 1990), organisations will only retain their scope and adaptability when organisational structures are in place which both enable and constrain. This insight resonates with the constructs of 'semistructure' (Brown and Eisenhardt, 1997), 'hypertext organization' (Nonaka, 1994), 'flexible firm’ (Volberda, 1996), and 'internal tensions' (Das and Teng, 2000), which we have extended and applied to corporate social networks.

Our study is characterised by several limitations. We addressed only the impact of structural antecedents on corporate network development and routines, thus ignoring the role of other important types of antecedents, such as culture, emotions, incentives, and technology (Cohen, 2007; Howard-Grenville, 2005; Rivkin and Siggelkow, 2003). We analysed one organisation at the corporate level and the other at the divisional level, which somewhat complicates the comparability. We collected primary data over a period of about three years; a longer time span would have provided a completer evolutionary picture. Our empirical evidence consists of two focal organisations, which engenders the risk of context-specific outcomes. Our contribution should, above all, be seen as an exploratory study that has started filling an important gap in the literature by generating propositions on the dynamic interplay 
of organisational structures, networks, and capabilities. Follow-up studies should assess the empirical robustness of our statements and the relative importance of the proposed structural antecedents in shaping the endogenous process of corporate network evolution. 


\section{REFERENCES}

Adler, P., and Kwon, S.-W. 2002. Social capital: Prospects for a new concept. Academy of Management Review, 27(1): 17-40.

Adler, P., Goldoftas, B., and Levine, D. 1999. Flexibility versus efficiency? A case study of model changeovers in the Toyota production system. Organization Science, 10(1): 43-68.

Argote, L. 1999. Organizational learning: Creating, retaining and transferring knowledge. Boston: Kluwer Academic Publishers.

Bartlett, C. 2006. Philips versus Matsushita: A new century, a new round. Harvard Business School Case 9-302-049. Boston: Harvard Business School.

Baum, J., Calabrese, T., and Silverman, B. 2000. Don't go it alone: Alliance network composition and startups' performance in Canadian biotechnology. Strategic Management Journal, 21: 267-294.

Baum, J., Rowley, T., Shipilov, A., and Chuang, Y-T. 2005. Dancing with strangers: Aspiration performance and the search for underwriting syndicate partners. Administrative Science Quarterly, 50: 536-575.

Baum, J., Shipilov, A., and Rowley, T. 2003. Where do small worlds come from? Industrial and Corporate Change, 12(4): 697-725.

Bazerman, M. 1997. Judgment in managerial decision making $\left(4^{\text {th }}\right.$ ed.). New York: John Wiley and Sons.

Becker, M. 2004. Organizational routines: A review of the literature. Industrial and Corporate Change, 13(4): 643-677.

Becker, M., Lazaric, N., Nelson, R., and Winter, S. 2005. Applying organizational routines in understanding organizational change. Industrial and Corporate Change, 14(5): 775-791.

Benner, M, and Tushman, M. 2002. Process management and technological innovation: A longitudinal study of the photograph and paint industries. Administrative Science Quarterly, 47: 676-706.

Benner, M., and Tushman, M. 2003. Exploitation, exploration, and process management: The productivity dilemma revisited. Academy of Management Review, 28(2): 238-256.

Bettis, R., and Wong, S.-S. 2003. Dominant logic, knowledge creation, and managerial choice. In M. Easterby-Smith and M. Lyles (Eds), The Blackwell handbook of organizational learning and knowledge management. Malden: Blackwell Publishing. 
Blumer, H. 1954. What is wrong with social theory? American Sociological Review, 18: 3-10.

Borgatti, S. and Foster, P. 2003. The network paradigm in organizational research: A review and typology. Journal of Management, 29: 991-1013.

Bowen, G. 2006. Grounded theory and sensitizing concepts. International Journal of Qualitative Methods, 5 (3) (http://www.ualberta.ca/ ijqm/).

Brass, D. and M. Burkhardt. 1992. Centrality and power in organizations. In N. Nohria and R. Eccles (eds), Networks and organizations: Structure, form, and action. Boston: Harvard Business School Press.

Brass, D., Galaskiewicz, J. , Greve, H., and Tsai, W. 2004. Taking stock of networks and organizations: A multilevel perspective. Academy of Management Journal, 47(6): 795-817.

Brown, S., and Eisenhardt, K. 2007. The art of continuous change: Linking complexity theory and time-paced evolution in relentlessly shifting organizations. Administrative Science Quarterly, 42(March): 1-34.

Burgelman, R. 2002. Strategy as vector and the inertia of coevolutionary lock-in. Administrative Science Quarterly, 47: 325-357.

Burt, R. 2002. Decay functions. Social networks, 22: 1-28.

Burt, R. 205. Brokerage and closure: An introduction to social capital. Oxford: Oxford University Press.

Cohen, M. 2007. Reading Dewey: Reflections on the study of routine. Organization Studies, 28(5): 773-786.

Cohen, W., and Levinthal, D. 1990. Absorptive capacity: A new perspective on learning and innovation. Administrative Science Quarterly, 35: 128-152.

Coleman, J. 1988. Social capital in the creation of human capital. American Journal of Sociology, 94: S95-S120.

Collis, D., and Montgomery, C. 1998. Creating corporate advantage. Harvard Business Review, May: 71-83.

Cyert, R., and March, J. 1992. A behavioral theory of the firm ( $2^{\text {nd }}$ ed.). Cambridge: Blackwell Publishers.

Daft, R., and Lengel, R. 1986. Organizational information requirements, media richness and structural design. Management Science, 32(5): 554-571. 
Das, T.K., and Teng, B.-S. 2000. Instabilities of strategic alliances: An internal tensions perspective. Organization Science, 11(1): 77-101.

Denrell, J., and March, J. 2001. Adaptation as information restriction: The hot stove effect. Organization Science, 12: 523-538.

De Visser, M., De Weerd-Nederhof, P., Faems, D., Song, M., Van Looy, B., and Visscher, K. 2010. Structural ambidexterity in NPD processes: A firm-level assessment of the impact of differentiated structures on innovation performance. Technovation, 30: 291-299.

DiMaggio, P., and Powell, W. 1983. The iron cage revisited: Institutional isomorphism and collective rationality in organizational fields. American Sociological Review, 48(April): 147-160.

Dougherty, D., and Hardy, C. 1996. Sustained product innovation in large, mature organizations: Overcoming innovation-to-organization problems. Academy of Management Journal, 39(5): 1120-1153.

Duncan, R. 1976. The ambidextrous organization: Designing dual structures for innovation. In R. Kilmann, L. Pondy, and D. Slevin (eds.), The management of organization, vol 1. New York: North-Holland.

Dyer, J., and Singh, H. 1998. The relational view : Cooperative strategy and sources of interorganizational competitive advantage. Academy of Management Review, 23: 660-679.

Eisenhardt, K. 1989. Building theories from case study research. Academy of Management Review, 14(4): 532-550.

Eisenhardt, K. and Bhatia, M. 2002. Organizational complexity and computation. In J. Baum (ed.), The Blackwell companion to organizations. Oxford: Blackwell.

Eisenhardt, K., and M. Graebner. 2007. Theory building from cases: Opportunities and challenges. Academy of Management Journal, 50(1): 25-32.

Elfring, T., and Hulsink, W. 2007. Networking by entrepreneurs: Patterns of tieformation in emerging organizations. Organization Studies, 28(12): 18491872.

Feldman, M., and Pentland, B. 2003. Reconceptualizing organizational routines as a source of flexibility and change. Administrative Science Quarterly, 48(March): 94-118.

Felin, T., and Hesterly, W. 2007. The knowledge-based view, nested heterogeneity, and new value creation: Philosophical considerations on the locus of knowledge. Academy of Management Review, 32(1): 195-218. 
Gagné, M., and Deci, L. 2005. Self-determination theory and work motivation. Journal of Organizational Behavior, 26(4): 331-362.

Galbraith, J. 1982. Designing the innovating organization. Organizational dynamics, 10(3): 5-25.

Gibson, C., and Birkinshaw, J. 2004. The antecedents, consequences and mediating role of organizational ambidexterity. Academy of Management Journal, 47: 209-226.

Gilsing, V., and Nooteboom, B. 2005. Density and strength of ties in innovation networks: An analysis of multimedia and biotechnology. European Management Review, 2: 179-197.

Gobbo, J., and Olsson, A. 2010. The transformation between exploration and exploitation applied to inventors of packaging innovation. Technovation, 30: 322-331.

Granovetter, M. 1973. The strength of weak ties. American Journal of Sociology, 78: 1360-1380.

Granovetter, M. 1985. Economic action and social structure: The problem of embeddedness. American Journal of Sociology, 91(3): 481-510.

Gulati, R. 1995. Social structure and alliance formation pattern: A longitudinal analysis. Administrative Science Quarterly, 40: 619-652.

Gulati, R., and Gargiulo, M. 1999. Where do interorganizational networks come from? American Journal of Sociology, 104(5): 1439-1493.

Gupta, A., Smith, K., and Shalley, C. 2006. The interplay between exploration and exploitation. Academy of Management Journal, 49(4)): 693-706.

Hagedoorn, J. 2006. Understanding the cross-level embeddedness of interfirm partnership formation. Academy of Management Review, 31(3): 670-680.F

Hannan, M. and Freeman, J. 1984. Structural inertia and organizational change. American Sociological Review, 49: 149-164.

Hannan, M. and Freeman, J. 1989. Organizational ecology. Cambridge: Harvard University Press.

Hansen, M. 1999. The search-transfer problem: The role of weak ties in sharing knowledge across organization subunits. Administrative Science Quarterly, 44: 82-111. 
Hansen, M., Podolny, J., and Pfeffer, J. 2001. So many ties, so little time; A task contingency perspective on corporate social capital. Research in the Sociology of Organizations. Greenwich: JAI Press.

Hargadon, A., and Sutton, R. 1997. Technology brokering and innovation in a product development firm. Administrative Science Quarterly, 42: 716-749.

Hiller, N., and Hambrick, D. 2005. Conceptualizing executive hubris: The role of (hyper-)core self-evaluations in strategic decision-making. Strategic Management Journal, 26: 297-319.

Hite, J., and Hesterly, W. 2001. The evolution of firm networks: From emergence to early growth of the firm. Strategic Management Journal, 22: 275-286.

Howard-Grenville, J. 2005. The persistence of flexible organizational routines: The role of agency and organizational context. Organization Science, 16(6): 618636.

Huberman, M., and Miles, M. 1994. Data management and analysis methods. In N. Denzin and Y. Lincoln (eds), Handbook of qualitative research. Thousand Oaks: Sage Publications.

ICFAI. 2005. Restructuring Philips. ICFAI Case 305-371-1. Chennai: International Center for Management Research.

InterConnect. 2007. DSM: Innovation in het bloed (DSM: Innovation in its blood). IMEC. 25: 21-23.

Jacobides, M. 2007. The inherent limits of organizational structure and the unfulfilled role of hierarchy: Lessons from a near-war. Organization Science, 18(3): 455477.

Janis, I. 1972. Victims of groupthink. Boston: Houghton Mifflin.

Johnson, G. 1988. Rethinking incrementalism. Strategic Management Journal, 9: 7591.

Kieser, A. Beck, N., and Tainio, R. 2001. Rules and organizational learning: The behavioral theory approach. In M. Dierkes, A. Berthoin Antal, J. Child, and I. Nonaka (eds), Handbook of organizational learning and knowledge. Oxford: Oxford University Press.

Kim, T.-Y, Oh, H., and Swaminathan, A. 2006. Framing interorganizational network change: A network inertia perspective. Academy of Management Review, 31(3): 704-720. 
Kirschbaum, R. 2005. Open innovation in practice: New business get built from a culture of change at the Dutch specialty materials company DSM. Research Technology Management, 48(4): 24-28.

Koka, B., Madhavan, R., and Prescott, J. 2006. The evolution of interfirm networks: Environmental effects on patterns of network change. Academy of Management Review, 31(3): 721-737.

Krackhardt, D. 1992. The strength of strong ties: The importance of philos in organizations. In N. Nohria and R. Eccles (eds), Networks and organizations: Structure, form, and action. Boston: Harvard Business School Press.

Levitt, B., March, J. 1995. Chester I. Barnard and the intelligence of learning. In O. Williamson (Ed.), Organization theory: From Chester Barnard to the present and beyond (expanded edition). New York: Oxford University Press.

Lewin, A., and Volberda, H. 1999. Prolegomena on coevolution: A framework for research on strategy and new organizational forms. Organization Science, 10(5): 519-534.

Lindblom, C. 1959. The science of "muddling through." Public Administration Review, 9(spring): 79-88.

March, J. 1991. Exploration and exploitation in organizational learning. Organization Science, 2: 71-87.

Marquis, C. 2003. The pressure of the past: Network imprinting in intercorporate communities. Administrative Science Quarterly, 48(December): 655-689.

Maurer, I., and Ebers, M. 2006. Dynamics of social capital and their performance implications: Lessons from biotechnology start-ups. Administrative Science Quarterly, 51(June): 262-292.

McEvily, B., and Zaheer, A. 1999. Bridging ties: a source of firm heterogeneity in competitive capabilities. Strategic Management Journal, 20: 1133-1156.

McPherson, M., Smith-Lovin, L., and Cook, J. 2001. Birds of a feather: Homophily in social networks. Annual Review of Sociology, 27: 415-444.

Meijer, E. 2006. DSM and innovation: A case study. International Journal of Technology Management, 34: 260-277.

Metze, M. 1997. Let's make things better. Nijmegen: SUN.

Meyer, J., and Rowan, B. 1977. Institutional organizations: Formal structure as myth and ceremony. American Journal of Sociology, 80: 340-363.

Miller, D. 1993. The architecture of simplicity. Academy of Management Review, 18: 644-659. 
Miller, D., and Dröge, C. 1986. Psychological and traditional determinants of structure. Administrative Science Quarterly, 31(December): 539-560.

Miller, D., and Friesen, P. 1982. Innovation in conservative and entrepreneurial firms: Two models of strategic momentum. Strategic Management Journal, 3(1): 125 .

Mintzberg, H. 1979. The structuring of organizations: A synthesis of the research. Englewood Cliffs, N.J.: Prentice-Hall.

Morgan, G. 1997. Images of organization. Thousand Oaks: Sage Publications.

Nelson, R., and Winter, S. 1982. An evolutionary theory of economic change. Cambridge: Belknap Press of Harvard University Press.

Nonaka, I. 1994. A dynamic theory of organisational knowledge creation. Organization Science, 5(1): 14-37.

Nooteboom, B. 2000. Learning and innovation in organizations and economies. Oxford: Oxford University Press.

Normann, R. 1971. Organizational innovativeness: Product variation and reorientation. Administrative Science Quarterly, 16: 203-215.

North, D. 1990. Institutions, institutional change and economic performance. Cambridge: Cambridge University Press.

Obstfeld, D. 2005. Social networks, the tertius iungens orientation, and involvement in innovation. Administrative Science Quarterly, 50: 100-130.

O'Reilly, C., and Tushman, M. 2004. The ambidextrous organization. Harvard Business Review, April: 74-81.

Parkhe, A., Wasserman, S., and Ralston, D. 2006. New frontiers in network theory development. Academy of Management Review, 31(3): 560-568.

Pentland, B., and Feldman, M. 2005. Organizational routines as a unit of analysis. Industrial and Corporate Change, 14(5): 793-815.

Pierce, J., and Delbecq, A. 1977. Organization structure, individual attitudes and innovation. Academy of Management Review, 2(1): 27-37.

Porter, M., and Van der Linde, C. 1995. Green and competitive: Ending the stalemate. Harvard Business Review, September: 120-134.

Powell, W., White, D., Koput, K., and Owen-Smith, J. 2005. Network dynamics and field evolution: The growth of interorganizational collaboration in the life sciences. American Journal of Sociology, 110(4): 1132-1205. 
Putnam, R. 2000. Bowling alone: The collapse and revival of American community. New York: Simon \& Schuster.

Ragin, C. 1987. The comparative method: Moving beyond qualitative and quantitative strategies. Berkeley: University of California Press.

Reagans, R., and McEvily, B. 2003. Network structure and knowledge transfer: The effects of cohesion and range. Administrative Science Quarterly, 48: 240-267.

Reagans, R., and Zuckerman, E. 2008. Why knowledge does not equal power: The network redundancy trade-off. Industrial and Corporate Change, 17(5): 903944.

Rivkin, J., and Siggelkow, N. 2003. Balancing search and flexibility: Interdependencies among elements of organizational design. Management Science, 49(3): 290-311.

Romanelli, E., and Tushman, M. 1994. Organizational transformation as punctuated equilibrium: An empirical test. Academy of Management Journal, 37: 11411166.

Rothaermel, F., and Hess, A. 2007. Building dynamic capabilities: Innovation driven by individual-, firm-, and network-level effects. Organization Science, 18(6): 898-921.

Rowley, T., Behrens, D., and Krackhardt, D. 2000. Redundant governance structures: An analysis of structural and relational embeddedness in the steel and semiconductor industries. Strategic Management Journal, 21: 369-386.

Ruef, M. 2002. Strong ties, weak ties and islands: Structural and cultural predictors of organizational innovation. Industrial and Corporate Change, 11(3): 427-449.

Seabright, M., Levinthal, D., and Fichman, M. 1992. Role of individual attachments in the dissolution of interorganizational relationships. Academy of Management Journal, 35(1): 122-160.

Siggelkow, N. 2007. Persuasion with case studies. Academy of Management Journal, 50(1): 20-24.

Simon, H. 1973. The organization of complex systems. In H. Pattee (ed.), Hierarchy theory: The challenge of complex systems. New York: George Braziller.

Simon, H. 1976. From substantive to procedural rationality. In S. Latsis (ed.), Method and appraisal in economics. Cambridge: Cambridge University Press.

Simsek, Z., Lubatkin, M., and Floyd, S. 2003. Inter-firm networks and entrepreneurial behavior: A structural embeddedness perspective. Journal of Management, 29(3): 427-442. 
Starbuck, W. 1985. Acting first and thinking later: Theory versus reality in strategic change. In J. Pennings (ed.), Organizational strategy and change, San Francisco: Jossey-Bass.

Steier, L. and Greenwood, R. 2000. Entrepreneurship and the evolution of angel financial networks. Organization Studies, 21(1): 163-192.

Suddaby, R. 2006. From the editors: Wat grounded theory is not. Academy of Management Journal, 49(4): 633-642.

Thompson, V. 1969. Bureaucracy and innovation. Alabama: University of Alabama Press.

Tushman, M., and O'Reilly, C. 1996. Ambidextrous organizations: Managing evolutionary and revolutionary change. California Management Review, 38 (4): 8-30.

Tushman, M., and Romanelli, E. 1985. Organizational evolution: A metamorphosis model of convergence and reorientation. In L. Cummings and J. Staw (eds), Research in Organizational Behavior, 7. Greenwich: JAI Press.

Uzzi, B. 1996. The sources and consequences of embeddedness for the economic performance of organizations: The network effect. American Sociological Review, 61(4): 674-698.

Uzzi, B. 1997. Social structure and competition in interfirm networks: The paradox of embeddedness. Administrative Science Quarterly, 42: 35-67.

Vanhaverbeke, W., and Peeters, N. 2005. Embracing innovation as strategy: Corporate venturing, competence building and corporate strategy making. Creativity and Innovation Management 14(3): 246-257.

Van Rooij, A. 2007. The company that changed itself: $R \& D$ and the transformation of DSM. Amsterdam: Amsterdam University Press.

Vlaar, P., Van den Bosch, F., and Volberda, H. 2007. Towards a dialectical perspective on formalization in interorganizational relationships: How alliance managers capitalize on the duality inherent in contracts, rules and procedures. Organization Studies, 28(4): 437-466.

Volberda, H. 1996. Toward the flexible form: How to remain vital in hypercompetitive environments. Organization Science, 7(4): 359-374.

Volberda, H., and Lewin, A. 2003. Co-evolutionary dynamics within and between firms: From evolution to co-evolution. Journal of Management Studies, 40(8): 2111-2136. 
Walker, G., Kogut, B., and Shan, W. 1997. Social capital, structural holes and the formation of an industry network. Organization Science, 8(2): 109-125.

Wasserman, S. and Faust, K. 1994. Social network analysis: Methods and applications. Cambridge: Cambridge University Press.

Watts, D. 1999. Networks, dynamics, and the small-world phenomenon. American Journal of Sociology, 105(2): 493-527.

Weick, K., and Roberts, K. 1993. Collective mind in organizations: Heedful interrelating on flight decks. Administrative Science Quarterly, 38: 357-381.

Weick, K., and Westley, F. 1996. Organizational learning: Affirming an oxymoron. In S. Clegg, C. Hardy, and W. Nord (Eds.), Handbook of organization studies. London: Sage Publications.

Wuyts, S., Colombo, M., Dutta, S., and Nooteboom, B. 2005. Empirical tests of cognitive distance. Journal of Economic Behavior \& Organization, 58: 277302.

Yin, R. 1994. Case study research: Design and methods. 2nd edn. Thousand Oaks: Sage. 